\title{
An assessment of perceived prioritisation and resource allocation for health policy and systems research in West Africa
}

\author{
Chigozie J Uneke ${ }^{a, c}$, Ijeoma N Okedo-Alexa, Ermel A Johnson ${ }^{b}$, \\ Ifeyinwa C Akamike ${ }^{a}$, Onyedikachi E Chukwu ${ }^{a}$, Irene I Eze ${ }^{a}$ and \\ Bilikis I Unekea
}

a African Institute for Health Policy and Health Systems, Ebonyi State University, Abakaliki, Nigeria

b West African Health Organisation, Bobo-Dioulasso, Burkina Faso

c Corresponding author: unekecj@yahoo.com

\section{Article history}

Publication date: 10 November 2021

Citation: Uneke CJ, Okedo-Alex IN, Johnson EA, Akamike IC, Chukwu OE,

Eze II, Uneke BI. An assessment of perceived prioritisation and resource allocation for health policy and systems research in West Africa. Public Health Res Pract. 2021;31(4):e3142122. https://doi. org/10.17061/phrp3142122

\section{Key points}

- Health research, and health policy and systems research (HPSR), are poorly prioritised for domestic funding in West African countries

- Although national research plans exist, poor capacity for conducting HPSR and a disconnect between researchers and policy makers continues to be a significant barrier to funding HPSR

- This study highlights the dominant role of donor agencies in funding and determining health research priorities, which does not always focus on local priorities

\section{Abstract}

Objectives: Globally, adequate funding is a strong underpinning to advance health policy and systems research (HPSR) and ensure its impact on strengthening health systems. This study examined the perceived prioritisation, and resource allocation for HPSR in West Africa.

Methods: A desk review was conducted of literature related to HPSR funding published between January 2010 and December 2019, sourced from various databases and government websites. This was followed by in-depth interviews with senior decision makers and HPSR and non-HPSR research leaders $(n=33)$ across nine West African countries: Benin, Burkina Faso, Côte d'Ivoire, Gambia, Ghana, Liberia, Nigeria, Senegal and Sierra Leone.

Results: The majority of the study participants were from ministries of health in their countries (66.7\%). All countries except Sierra Leone had a program dedicated to health policy research and/or health planning/program research. There was no specific funding for health research nor HPSR in most countries and a mixed model (demand and supply led) was employed in most instances. HPSR was only considered a priority in two of the nine countries and specific funding for it was non-existent in all nine countries. In all countries, donor agencies played predominant roles in setting health research priorities and resource allocation decisions. Infectious disease and maternal/child health research were the research categories with the highest level of funding. There was limited capacity for HPSR, with a pronounced gap between researchers and policy makers. Stakeholder advocacy, basket funding for health research, multi-stakeholder institutional and individual HPSR capacity building were the major recommendations for improving the status and funding of HPSR.

Conclusions: This study showed that both health research and HPSR were considered low priorities, with no designated funding (budget line) and inadequacy of funding disbursement in the surveyed countries in West Africa. 
Health research was largely conducted as prioritised and funded by the donor agencies. Given donor fatigue and the transitioning of donor funding, and the pivotal role of HPSR in strengthening health systems, there is an urgent need for West African states to commit to prioritising and funding HPSR and HPSR capacity development.

\section{Introduction}

Within the past decade, there has been an increasing recognition worldwide of the importance of the use of evidence in the development of health policies. This has led to the promotion of health policy and systems research (HPSR), which has been described as one of the emerging areas of research capable of bridging the huge divide between research and policy. ${ }^{1}$

Although gaps and disparities still exist in the relatively new and rapidly evolving field of HPSR, there has been significant and steady progress in capacities for HPSR in low- and middle-income countries (LMICs) where health systems are least resilient and strengthening of health systems is most needed. ${ }^{2}$

Globally, adequate funding is a strong underpinning factor to further HPSR and ensure its impact on strengthening health systems. ${ }^{3,4}$ Committed funding is critical for the institutionalisation of HPSR, especially in LMICs. ${ }^{5}$

In contrast to higher levels of government funding for HPSR in high-income countries ${ }^{6}$, funding for HPSR in LMICs has been largely donor driven. There has been a conscious effort to increase funding allocation for HPSR in LMICs over the years. ${ }^{2}$ It is noteworthy that as at 2017 , development assistance for health donor commitments to funding HPSR-related activities in LMICs has progressively increased since 2000 with a peak in 2010 , and has remained steady since $2011 .{ }^{4}$ Sub-Saharan African countries, especially those in West Africa, have been chief beneficiaries of these HPSR funds due to the prevailing disease burden and paucity of domestic funding for HPSR. ${ }^{4}$ The reliance of health systems (HPSR inclusive) on donor funds has, however, resulted in donor dependence, poor local commitment to support HPSR and poor use of generated research evidence for policy making. ${ }^{7,8}$ At the institutional level in West Africa, funding to support research infrastructure and build HPSR researcher capacity within and outside the various organisations remains insufficient. Research-related activities are mostly funded through donor support, or by out-of-pocket contributions by researchers. ${ }^{9,10}$ This further highlights the need for institutional strengthening for both research governance as well as the undertaking of HSPR.

There has been growing focus on the need to promote domestic funding as the mainstay for HPSR funding, rather than the exception. This has been necessitated by impending and actual donor fatigue and funding transition in many contexts as shown by the funding cutbacks and waning development assistance for health and HPSR. Additionally, the inherent advantages of priority-based research, research involvement and ownership by stakeholders with increased chances of uptake for evidence-informed policy making cannot be over-emphasised. As a backdrop towards promoting local fund ownership for HPSR in West Africa and similar contexts, this study examined the perceived prioritisation and resource allocation for health research and HPSR in nine countries of the West African subregion.

\section{Methods}

\section{Study population}

The following countries were involved in the study: Benin, Burkina Faso, Côte d'Ivoire, Gambia, Ghana, Liberia, Nigeria, Senegal and Sierra Leone. Using the networks of the West African Health Organization (WAHO), contacts from all 15 countries in the Economic Community of West African States (ECOWAS) were identified and invited to participate via email, SMS (text messaging) and telephone calls. Contacts from nine countries responded and agreed to participate in the study. The study participants were stakeholders selected from organisations such as ministries of health, ministries of finance, and research directorate/science and technology councils, and HPSR and non-HPSR health researchers from tertiary institutions. Participants were purposively selected based on role, pre-specified criteria (such as position/cadre, research accomplishments, publications and in-country recommendations) and representativeness. Snowballing was also used to identify participants based on recommendations, links and referrals from the participants. Purposive selection of both policy makers and researchers has been adopted in previous studies. ${ }^{11}$

\section{Study design}

This study was designed to answer the following question: what is the perception prioritisation, and resource allocation for health research and HPSR in West Africa? The study involved a desk review and in-depth interviews with senior decision makers, HPSR and nonHPSR researchers on the perceived prioritisation and resource allocation for health research and HPSR. 


\section{Desk review}

The aim of the desk review was to identify academic and grey literature evidence on research and health research for development (including HPSR) and funding for such research in the countries selected for the study. The search period was 1 January 2010 to 31 December 2019. The desk review investigated available financial and human resources on research for development, national research policy and frameworks, funds allocated to HPSR and the sources of research funding in the various countries.

The following databases and sources were searched: PubMed, Google Scholar, grey literature, published government reports, national accounts, budget expenditure reports, reports describing national research funding systems and priorities, national science funding agency websites and their annual reports. A combination of search terms were used to seek information in the various countries, including 'health systems', 'research funding', 'health policies', 'funding', 'allocation', 'budget', 'percentage of funding', 'institutions of decision-making', 'decision-making criteria' and 'sources of funding'.

\section{In-depth interviews}

The in-depth interviews were conducted for three categories of interviewees: senior health leaders, research leaders in HPSR, and non-HPSR health research leaders. The senior health leaders were selected on the basis of being mid- to senior-level career policy makers in the ministry of health and/or its counterpart departments and government agencies. They were identified by snowballing and recommendations. The HPSR researchers and non-HPSR research leaders were selected based on research accomplishment, publication and in-country recommendation (snowballing). Three different interview guides were designed based on the study objectives and review of existing literature for the different categories of interviewees.

The interview guide for senior health leaders explored the availability and content of research for health policy planning, research funding allocation decisions, and considerations, importance and public funding of HPSR. The interview guides for HPSR and non-HPSR research leaders assessed resource allocation decisions for research for health, the nature, determinants and sources of research funding, adequacy of HPSR funding, and capacity.

Each interview took 45-60 minutes and all were conducted in one sitting, using phone calls and Zoom videoconferencing (San Jose, CA: Zoom Video Communications Inc). The interviews were conducted by the research team who were professionals with postgraduate training in HPSR, and were recorded using the recording functions of Zoom and phones. The study participants were contacted by a combination of calls, emails and text messages in order to determine availability and interest in the study. Following confirmation of participation, the interviews were then scheduled and conducted based on the participants' preferences regarding time and mode. A total of 33 interviews were held in either English or French languages, based on the language spoken in the interviewees' countries.

\section{Data analysis}

The transcribed interviews were analysed using Giorgi's phenomenological approach ${ }^{12}$, which was further elaborated by Albert et al. ${ }^{13}$ The analysis followed the following steps: 1) reviewing all the textual data to gain an overall impression; 2) identifying all comments that appeared noteworthy to the research, extracting these meaning units; and 3) independent abstracting of the meaning units, followed by discussion and consensus. The recordings were first transcribed verbatim and some responses quoted verbatim in order to retain the direct comments of the interviewees. The interview guides were used for the development of themes that formed the initial coding framework. Afterwards, we compared the transcripts and the coding framework to detect other themes not present in the coding framework. We then applied the revised coding framework to all the transcripts to generate the final coding framework. Data coding was done by two data coders and the results summarised using tables and prose.

\section{Ethics approval}

The University Research Ethics Committee of Ebonyi State University, Abakaliki, Nigeria (reference number: EBSU/DRIC/UREC vol. 05/077) approved this study.

\section{Results}

\section{Desk review findings}

The search identified a national research policy/ framework document for all the countries except Burkina Faso. Generally, there was paucity of information on funding for research and none of the identified publications assessed or reported on any funding for HPSR specifically. Most funding for research and development came from donors. Regarding research capacity, the rate of researchers in seven of the countries studied was 31-36 researchers per 1 million inhabitants, and these were mostly male researchers. ${ }^{9}$ Inadequacy of researchers and researcher capacity was highlighted as a concern in some countries. The results of the desk review findings are summarised in Table 1. 
Table 1. Summary of outcome of desk review on the status of research and development in nine West African countries

\begin{tabular}{|c|c|c|c|c|c|c|}
\hline \multirow[t]{2}{*}{ Country } & \multirow{2}{*}{$\begin{array}{l}\text { Number of } \\
\text { relevant } \\
\text { publications } \\
\text { found }\end{array}$} & \multicolumn{2}{|c|}{ Research and development (R\&D) data ${ }^{a}$} & \multirow{2}{*}{$\begin{array}{l}\text { National research policy/ } \\
\text { framework }\end{array}$} & \multirow{2}{*}{$\begin{array}{l}\text { Amount } \\
\text { allocated } \\
\text { to HPSR }\end{array}$} & \multirow[t]{2}{*}{ Main sources of research funding } \\
\hline & & $\begin{array}{l}\text { Financial resources } \\
\text { (PPP\$ unless otherwise specified) }\end{array}$ & $\begin{array}{l}\text { Human resources/ } \\
\text { research capacity }\end{array}$ & & & \\
\hline Benin & 1 & R\&D funding: $<1 \%$ of GDP & $\begin{array}{l}\text { About } 2443 \text { people in all categories } \\
\text { engaged in research and } \\
\text { innovation Researchers: } 1302 \\
\text { Male: } 79 \% \\
\text { Female: } 21 \% \\
\text { Higher education research } \\
\text { structures: } 32 \% \\
\text { Other public structures: } 20 \% \text { Non- } \\
\text { government organisations: } 35 \% \\
\text { Companies: } 13 \%\end{array}$ & $\begin{array}{l}\text { National Fund for } \\
\text { Scientific Research and } \\
\text { Technological Innovation } \\
\text { Beninese Agency for the } \\
\text { Valorization of Research } \\
\text { Results and Technological } \\
\text { Innovation }\end{array}$ & None & $\begin{array}{l}\text { Mainly by international donor } \\
\text { agencies including WHO, WAHO, } \\
\text { DFID, IDRC, Bill \& Melinda Gates } \\
\text { Foundation, Welcome Trust, USAID, } \\
\text { EDCTP, UNICEF, World Bank }\end{array}$ \\
\hline $\begin{array}{l}\text { Burkina } \\
\text { Faso }\end{array}$ & 5 & $\begin{array}{l}\text { R\&D spending as } \% \text { of GDP: } 0.2 \% \\
\text { R\&D spending: } \$ 65228 \mathrm{k} \\
\text { R\&D spending by sector of } \\
\text { performance: } \\
\text { Government } \$ 23188 \mathrm{k} \\
\text { Universities } \$ 39055 \mathrm{k} \\
\text { Private non-profit } \$ 2986 \mathrm{k}\end{array}$ & $\begin{array}{l}\text { Number of researchers per million } \\
\text { inhabitants: } 47 \\
\text { Male: } 85 \% \\
\text { Female: } 15 \%\end{array}$ & NA & None & $\begin{array}{l}\text { In } 2008, \text { foreign partners funded } \\
87 \% \text { of research for health projects }\end{array}$ \\
\hline $\begin{array}{l}\text { Côte } \\
\text { d'lvoire }\end{array}$ & 5 & $\begin{array}{l}\text { R\&D spending as \% of GDP: NA } \\
\text { R\&D spending: NA }\end{array}$ & $\begin{array}{l}\text { Number of researchers per million } \\
\text { inhabitants: } 69 \\
\text { Male: } 84 \% \\
\text { Female: } 17 \%\end{array}$ & $\begin{array}{l}\text { Côte d'Ivoire National } \\
\text { Development Plan }\end{array}$ & None & $\begin{array}{l}\text { Mainly by international donor } \\
\text { agencies including WHO, WAHO, } \\
\text { DFID, IDRC, Bill \& Melinda Gates } \\
\text { Foundation, Wellcome Trust, USAID, } \\
\text { EDCTP, UNICEF, World Bank }\end{array}$ \\
\hline Gambia & 2 & $\begin{array}{l}\text { R\&D spending as } \% \text { of GDP: } 0.1 \% \\
\text { R\&D spending: } \$ 3544 \mathrm{k} \\
\text { R\&D spending by sector of } \\
\text { performance: } \\
\text { Government } \$ 1929 \mathrm{k} \\
\text { Private non-profit } \$ 1615 \mathrm{k}\end{array}$ & $\begin{array}{l}\text { Number of researchers per million } \\
\text { inhabitants: } 31 \\
\text { Male: } 80 \% \\
\text { Female: } 20 \%\end{array}$ & $\begin{array}{l}\text { National Health Research } \\
\text { Policy, } 2002 \\
\text { Strategic Health Research } \\
\text { Plan, 2008-2012 }\end{array}$ & None & $\begin{array}{l}\text { Medical Research Council Gambia, } \\
\text { a non-governmental research } \\
\text { institute }\end{array}$ \\
\hline
\end{tabular}


Table 1 cont. Summary of outcome of desk review on the status of research and development in nine West African countries

\begin{tabular}{|c|c|c|c|c|c|c|}
\hline \multirow[t]{2}{*}{ Country } & \multirow{2}{*}{$\begin{array}{l}\text { Number of } \\
\text { relevant } \\
\text { publications } \\
\text { found }\end{array}$} & \multicolumn{2}{|c|}{ Research and development (R\&D) data ${ }^{a}$} & \multirow{2}{*}{$\begin{array}{l}\text { National research policy/ } \\
\text { framework }\end{array}$} & \multirow{2}{*}{$\begin{array}{l}\text { Amount } \\
\text { allocated } \\
\text { to HPSR }\end{array}$} & \multirow[t]{2}{*}{ Main sources of research funding } \\
\hline & & $\begin{array}{l}\text { Financial resources } \\
\text { (PPP\$ unless otherwise specified) }\end{array}$ & $\begin{array}{l}\text { Human resources/ } \\
\text { research capacity }\end{array}$ & & & \\
\hline Ghana & 4 & $\begin{array}{l}\text { R\&D spending as \% of GDP: } 0.4 \% \\
\text { R\&D spending: } \$ 276603 \mathrm{k} \\
\text { R\&D spending by sector of } \\
\text { performance: } \\
\text { Business } \$ 421197 \\
\text { Government } \$ 265665 \mathrm{k} \\
\text { Universities } \$ 10501 \mathrm{k} \\
\text { Private non-profit } \$ 15954\end{array}$ & $\begin{array}{l}\text { Number of researchers per million } \\
\text { inhabitants: } 37 \\
\text { Male researchers: } 82 \% \\
\text { Female researchers: } 18 \% \\
\text { At all levels, HPSR capacity exists } \\
\text { in Ghana but is somewhat fragile }\end{array}$ & $\begin{array}{l}\text { National Research Fund } \\
\text { Bill, } 2019\end{array}$ & None & $\begin{array}{l}\text { (a) Seed money of fifty million } \\
\text { Ghana Cedis specifically allocated } \\
\text { for the start-up of the fund; (b) an } \\
\text { amount equivalent to } 1 \% \text { of the GDP } \\
\text { approved by Parliament annually; } \\
\text { (c) grants, donations, gifts and other } \\
\text { voluntary contributions to the Fund; } \\
\text { (d) moneys that accrue from the } \\
\text { Endowment Fund created by the } \\
\text { Fund }\end{array}$ \\
\hline Liberia & 3 & $\begin{array}{l}\text { Total health spending as } \% \text { of } \\
\text { GDP: } 6.74 \% \text { in } 2018^{\mathrm{b}} \text { Health } \\
\text { expenditure per capita of Liberia } \\
\text { increased from US } \$ 8 \text { in } 2003 \\
\text { to US } \$ 57 \text { in } 2017 \text { growing at an } \\
\text { average annual rate of } 21.5 \%\end{array}$ & $\begin{array}{l}\text { In general, there is limited } \\
\text { availability of human resources for } \\
\text { health which is even more marked } \\
\text { in the field of research. Regarding } \\
\text { ethics committees, not all members } \\
\text { had received training, although } \\
\text { they offered training in research } \\
\text { methodology. }\end{array}$ & $\begin{array}{l}\text { National Research } \\
\text { for Health Policy and } \\
\text { Strategy, } 2018 \\
\text { National Health and } \\
\text { Social Welfare Policy, } \\
2011-2021 \\
\text { National Research and } \\
\text { Ethics Board } \\
\text { National Public Health } \\
\text { Institute of Liberia }\end{array}$ & None & $\begin{array}{l}\text { Health research is largely funded } \\
\text { through collaborative initiatives, } \\
\text { mainly private multilateral } \\
\text { institutions, research sponsors } \\
\text { and partners/donors from foreign } \\
\text { sources. Currently, AID development } \\
\text { partners provide most of the funding } \\
\text { for Research for Health activities }\end{array}$ \\
\hline Nigeria & 5 & $\begin{array}{l}\text { R\&D spending as } \% \text { of GDP: } 0.1 \% \\
\text { R\&D spending: } \$ 806455 \mathrm{k} \\
\text { R\&D spending by sector of } \\
\text { performance: } \\
\text { Government } \$ 283784 \mathrm{k} \\
\text { Universities } \$ 522671 \mathrm{k}\end{array}$ & $\begin{array}{l}\text { Number of researchers per million } \\
\text { inhabitants: } 38 \\
\text { Male: } 77 \% \\
\text { Female: } 23 \%\end{array}$ & $\begin{array}{l}\text { National Strategic Health } \\
\text { Plan } \\
\text { National Code of Health } \\
\text { Research Guidelines for } \\
\text { Accessing Institutional } \\
\text { Based Research Fund }\end{array}$ & None & $\begin{array}{l}\text { Locally by the Tertiary Education } \\
\text { Trust Fund. Mainly by international } \\
\text { donor agencies including WHO, } \\
\text { WAHO, DFID, IDRC, Bill \& Melinda } \\
\text { Gates Foundation, Wellcome Trust, } \\
\text { USAID, EDCTP, UNICEF, World Bank }\end{array}$ \\
\hline Senegal & 1 & $\begin{array}{l}\text { R\&D spending as } \% \text { of GDP: } 0.4 \% \\
\text { R\&D spending: } \$ 148696 \mathrm{k} \\
\text { R\&D spending by sector of } \\
\text { performance: } \\
\text { Business } \$ 500938 \\
\text { Government } \$ 77392 \mathrm{k} \\
\text { Universities } \$ 46737 \mathrm{k} \\
\text { Private non-profit } \$ 24065 \mathrm{k}\end{array}$ & $\begin{array}{l}\text { Number of researchers per million } \\
\text { inhabitants: } 369 \\
\text { Male: } 75 \% \\
\text { Female: } 25 \% \\
\text { There is a national network of health } \\
\text { research and development }\end{array}$ & $\begin{array}{l}\text { Health research policy } \\
\text { A strategic health } \\
\text { research plan } \\
\text { National health research } \\
\text { system }\end{array}$ & None & $\begin{array}{l}\text { Multilateral and bilateral donor } \\
\text { funding were the most important } \\
\text { sources of funding for health } \\
\text { research }\end{array}$ \\
\hline
\end{tabular}


Table 1 cont. Summary of outcome of desk review on the status of research and development in nine West African countries

\begin{tabular}{|c|c|c|c|c|c|c|}
\hline \multirow[t]{2}{*}{ Country } & \multirow{2}{*}{$\begin{array}{l}\text { Number of } \\
\text { relevant } \\
\text { publications } \\
\text { found }\end{array}$} & \multicolumn{2}{|c|}{ Research and development (R\&D) data ${ }^{a}$} & \multirow{2}{*}{$\begin{array}{l}\text { National research policy/ } \\
\text { framework }\end{array}$} & \multirow{2}{*}{$\begin{array}{l}\text { Amount } \\
\text { allocated } \\
\text { to HPSR }\end{array}$} & \multirow[t]{2}{*}{ Main sources of research funding } \\
\hline & & $\begin{array}{l}\text { Financial resources } \\
\text { (PPP\$ unless otherwise specified) }\end{array}$ & $\begin{array}{l}\text { Human resources/ } \\
\text { research capacity }\end{array}$ & & & \\
\hline $\begin{array}{l}\text { Sierra } \\
\text { Leone }\end{array}$ & 1 & $\begin{array}{l}\text { Health spending as } \% \text { of total } \\
\text { government expenditure in } 2016 \text { : } \\
11 \%^{c}\end{array}$ & $\begin{array}{l}\text { There is no dedicated masters or } \\
\text { doctoral level training in research } \\
\text { for health, and, as a result, there } \\
\text { are very few health researchers } \\
\text { in the country. The small number } \\
\text { of health researchers are typically } \\
\text { combining multiple tasks or jobs } \\
\text { with limited grants and research } \\
\text { management skills. }\end{array}$ & $\begin{array}{l}\text { National health sector } \\
\text { strategic plan, 2017-2021 }\end{array}$ & None & $\begin{array}{l}\text { UNDP, UNICEF and UNFPA, the } \\
\text { World Bank, DFID, the Africa } \\
\text { Development Bank }\end{array}$ \\
\hline
\end{tabular}

HPSR = health policy and systems research; GDP = Gross domestic product; PPP = purchasing power parity; NA = not available; WHO = World Health Organization; WAHO = West African Health Organization; DFID = former UK Department for International Development; IDRC = International Development Research Centre; USAID = United States Agency for International Development, EDCTP = European \& Developing Countries Clinical Trials Partnership; UNDP = United Nations Development Programme; UNFPA = United Nations Population Fund

Source: UNESCU Institute for Statistics (uis.unesco.org/apps/visualisations/research-and-development-spending/)

b Source: The World Bank: data (data worldbank org/indicator/SH.XPD.CHEX.GD.ZS?end =2018\&locations $=$ LR \&start=2000\&view $=$ chart)

Source: WHO Global Health Expenditure Database (apps.who.int/nha/database/ViewData/Indicators/en) 


\section{In-depth interviews findings}

A total of 33 participants from across nine African countries were interviewed, comprising 20 senior health leaders, 10 non-HPSR research leaders and 3 research leaders in HPSR (Table 2). The majority were from the ministries of health $(20 / 33,61 \%)$. About half had an M.Sc. (15/33, 46\%) or PhD (15/33, 46\%) as their highest academic qualification and $42 \%$ had spent more than 5 years in their designated roles.

Table 2. Number and role of interviewees from each country $(n=33)$

\begin{tabular}{lccc}
\hline Country & $\begin{array}{c}\text { Senior health } \\
\text { leaders }\end{array}$ & $\begin{array}{c}\text { Non-HPSR } \\
\text { research } \\
\text { leaders }\end{array}$ & $\begin{array}{c}\text { HPSR } \\
\text { research } \\
\text { leaders }\end{array}$ \\
\hline Benin & 2 & 1 & 0 \\
Burkina Faso & 2 & 2 & 0 \\
Côte d'Ivoire & 2 & 0 & 0 \\
Gambia & 2 & 2 & 1 \\
Ghana & 2 & 2 & 1 \\
Liberia & 1 & 0 & 0 \\
Nigeria & 5 & 1 & 1 \\
Senegal & 2 & 0 & 0 \\
Sierra Leone & 2 & 2 & 0 \\
\hline TOTAL & 20 & 10 & 3 \\
\hline
\end{tabular}

HPSR = health policy and systems research

Interviews with senior health leaders from the nine countries revealed that all the countries except Sierra Leone had a health research policy and/or health research plan/program. However, the plan Gambia was reported to have expired in 2014, while that of Nigeria was an internal plan at the level of the different ministries. HPSR was only considered among the priorities in the research plan and funding allocation in two countries (Liberia and Senegal). In all nine countries, donor agencies played predominant roles in resource allocation decisions for research for health. There was no specific funding for health research in most countries and a mixed model (demand and supply led) was employed in most instances. Public funding for HPSR was provided in only three countries: Côte d'Ivoire, Senegal and Nigeria (see Supplementary File 1, available from: doi.org/10.6084/ m9.figshare. 16929397).

According to the feedback from non-HPSR research leaders from six countries, donor interests were a criterion for decision making health research funding allocations in four of the six countries (Gambia, Ghana, Nigeria and Sierra Leone). Political interests and benefits, and impact on population health, were some reasons for possible public funding of HPSR, while insufficient funds/resources was a recurring reason for non-funding in Burkina Faso, Gambia, Ghana and Sierra Leone. Research on infectious disease and maternal and child health research were the research categories with higher levels of funding in three of four countries with a response on the issue (Gambia, Ghana and Sierra Leone). Benin had the highest rating for adequacy of HPSR funding (3 out of 5) based on the interviewees' assessment, while Gambia had the lowest rating (1 out of 5). Ghana had the highest rating for HPSR capacity and leadership (5 out of 5) (see Supplementary File 2, available from: doi.org/10.6084/ m9.figshare.16929400).

Three HPSR research leaders (from Gambia, Nigeria and Ghana) participated in the study. Only Nigeria was reported to have a local source of funding for research generally (the Tertiary Education Trust Fund) in addition to donor funding. Participants from all three countries gave low ratings for HPSR in their country as government funding was non-existent. Nigeria was rated the maximum score of 5 for HPSR community capacity and leadership due to the availability of productive HPSR researchers (see Supplementary File 3, available from: doi.org/10.6084/m9.figshare.16929403).

\section{What senior health leaders said about HPSR funding}

\section{Why public funding is provided for HPSR}

Participants from all the four countries (Côte d'Ivoire, Ghana, Nigeria and Senegal) who indicated that public funding for HPSR was available also stated that this funding was inadequate. The major reasons for provision of public funding for HPSR were the need for evidence to aid decision making and improve interventions by the government, and the demand for evidence by policy makers and health emergencies such as the coronavirus disease 2019 (COVID-19) pandemic. Participants noted:

Government may provide funds for HPSR if they want to provide evidence-based service delivery. The only problem is that the budget is not sufficient for the many challenges in the country. (Senior health leader, Ghana)

Also, when COVID-19 pandemic came, they set up a treatment research group which all the directors of research institutions like NIMR [Nigerian Institute of Medical Research] belonged to and made them to know the importance of research so they have no other way to go [than to support research]. (Senior health leader, Nigeria)

The need to promote evidence to guide policy processes appeared to be one of the major drivers of the provision of budget for HPSR. Among the countries surveyed, Côte d'Ivoire, Ghana, Nigeria and Senegal were among the countries with a comparatively higher level of funding for health research including HPSR. The participants implied that this was due to the increased awareness of the value of evidence-informed policy making among the policy actors and other government stakeholders. 


\section{Advocates for HPSR funding in countries where funding exists}

The main advocates listed were government ministries, research institutions, non-governmental organisations (NGOs), civil society organisations and passionate individuals.

We have a coalition of NGOs in health and they have been very vociferous when it comes to funding for HPSR, we also have 'STAR Ghana'. [STAR Ghana Foundation is a non-governmental organisation in Ghana which promotes active citizenship for change by supporting civil society to engage with government and drive forward a development agenda]. Also individuals like myself and directors of research in the ministry of health make a lot of noise about funding for HPSR. (Senior health leader, Ghana)

Côte d'Ivoire, Ghana, Nigeria and Senegal are among the countries with higher numbers of NGOs and civil society organisations in West Africa. These organisations are known to be champions and promoters of better health policies through the use of research evidence. ${ }^{14}$ These countries also appear to have stronger research institutions as shown by the high volume of published research work emanating from their universities and other higher institutions. ${ }^{15}$

\section{Reasons for non-funding of HPSR in countries with non-existent and/or inadequate funding}

Some of the reasons for non-funding of HPSR that were highlighted across the countries were: lack of importance, low prioritisation, insufficient funds, poor knowledge and capacity for HPSR, absence of support services like national ethics committees, internet access, donor dependence and political campaign reasons. Interviewees noted:

The government only sees the need to establish a directorate of research but in the actual sense they do not see the need to carry out the actual research activities. (Senior health leader, Gambia)

Lack of importance placed on research despite the fact that everybody agrees on the usefulness. (Senior health leader, Benin)

The politicians want results that they can use to buy votes. Research results will not come in 1 month or even 1 year. And the politician wants something that when they fund, people can see immediately and vote for them in the next election. Since research findings and results are unlikely to produce that for them immediately, they would prefer something else like roads which everybody will see. (Senior health leader, Nigeria)

In countries such as Nigeria, Gambia and Benin, interviewees reported that major barriers to the funding of health research including HPSR were the lack of political will and sufficient government interest in research evidence. Policy decisions were made without reference to research evidence because the politicians felt they had an easier option for information outside research evidence that is timelier, the interviewees suggested.

\section{Specific policies and steps to improve public funding for HPSR}

Recommendedations to improve public funding included: in-country and regional level multi-stakeholder advocacy (all stakeholders involved in resource decision making, allocation and release), documented strategic plans, strategic research dissemination, early stakeholder engagement in research, bridging the researcher-policy maker gap and institutionalisation of HPSR into existing programs and structures. Interviewees said:

First we need to have a health research and systems policy and a strategic plan without which you do not have a legal mandate to operate. (Senior health leader, Gambia)

Advocacy to be done at the National legislature and other stakeholders on the importance of health policy and system research will improve allocation of funding to such in the country. (Senior health leader, Liberia)

\section{Specific policies or steps to strengthen the HPSR capacity and leadership}

The recommendations to strengthen HPSR capacity were: individual and institutional capacity building for researchers and decision makers; employment of evidence specialists in research directorates; linkages between universities and ministries of health/other decision makers; data sharing platforms; provision of grants; and other incentives.

Capacity building for decision makers is very important. (Senior health leader, Burkina Faso)

I would like a situation of strong cooperation between the policy makers and the scientific community. (Senior health leader, Nigeria)

The actual orientation of setting up a national fund for research is a starting point. All research funds will go to this institute and will allocate fund base on priorities. (Senior health leader, Benin)

Strong emphasis was made by the respondents on the need for strengthening of critical competences and capacities of both researchers and policy makers in the evidence-to-policy process. Respondents also advocated for strong leadership that will promote the use of evidence in policy making as a major facilitator of the allocation of funding to health research. 


\section{Right funding mix for HPSR in the next 3-5 years}

Study participants emphasised the importance of a common basket fund for health research - a central funding pool for allocation based on need - as well as research teams within departments of the ministry of health, and increased country ownership of research funding. Various forms of funding initiatives were proposed by the respondents, with greatest emphasis on basket and catalytic funding mechanisms. Basket funds are a mechanism for pooling funds from various sources, typically governments, donors and the private sector to support priorities and ensure adequate resource allocation for agreed upon program areas. ${ }^{16}$ Catalytic funding refers to micro-grants, early investments, or startup capital given when a small amount of investment and guidance has the potential to yield big results. ${ }^{17}$

According to the respondents, this could facilitate access to the funding required to undertake meaningful health research with evidence channelled into the policymaking process.

A need to have a common basket for health research which can be allocated to any department depending on their need and country priorities; instead of having a particular funding for each research. (Senior health leader, Burkina Faso)

I would like to see increased government interest in research backed up with funding as against the present total reliance on donors for every research [project]. (Senior health leader, Gambia)

Establishment of catalytic funds to accompany implementation research, capacity building in research for professional researchers with active collaboration between universities, donors and government. (Senior health leader, Senegal)

\section{Discussion}

This study assessed perceived prioritisation, and resource allocation of HPSR funding in nine countries of Africa. The outcomes of this survey generally showed that HPSR was only considered a priority in two of the nine countries and its funding was non-existent and/or grossly inadequate in all nine countries. Most of the funding for health research was provided by international donors and development partners. Donor interests and priorities were the major criteria for existing research priorities in the countries. Apart from Nigeria, where an agency was specifically established (Tertiary Education Trust Fund) to fund research and other development activities in tertiary institutions, there are no other similar research organisations in other countries.

In countries with capacity for HPSR (Ghana and Nigeria), such capacity was mostly concentrated in universities, while directorates/departments of research faced major technical and human resource challenges. Stakeholder advocacy, basket funding for health research, and multi-stakeholder institutional and individual capacity building for HPSR were the major recommendations proffered by study participants for improving the status and funding of HPSR in their nations.

The low priority placed on HPSR in most of the countries could reflect poor awareness of the field and its importance for health policy and systems strengthening. However, this was not peculiar to HPSR, as health research generally was not prioritised despite acclaimed knowledge of its usefulness. Nonetheless, biomedical, epidemiological and clinical research typically received more attention as a result of donors funding these areas; a typical case of 'he who pays the piper calls the tune'. Grépin and colleagues used the OECD Creditor Reporting System Database to show that between 2000 2014 , donor funding for health and population activities was more than US\$245 billion and 16\% of these funded projects focused on health policy and systems. ${ }^{4}$ About $2 \%$ of the total commitments (US\$4 billion) were directed to HPSR-related activities. The importance of committed funding by national governments to HPSR such as implementation research has been well highlighted. ${ }^{5}$

The overarching and heavy influence of donors on country-level health priorities leaves much to be desired because of the inherent disadvantage of sidelining country-level priorities. A country's ability to bring its influence to bear on decisions and policies becomes increasingly difficult when it does not provide the funding itself. Although the clamour for decolonising global health has been getting louder ${ }^{18}$, donor dependence (and the implicit subservience) rather than a partnership with research funders will continue to compromise the ability to focus on country-level priorities. Local leaders need to begin to see domestic funding as the norm rather than the exception.

It is not news that countries in Africa face burgeoning health problems, however ensuring progressive commitment to the allocation and eventual release of allocated funds towards national health research systems is a critical step towards institutionalising structures that strengthen the systemic response to the high burden of diseases. The weakness of national health research systems in Africa have been previously reported. ${ }^{19}$

Although about $40 \%$ of the countries in this study had budget lines for research in general, funding was primarily from multilateral and bilateral donors. While advocacy by stakeholders on greater prioritisation and funding of HPSR was strongly recommended, this requires patience, should not be a one-off process and should possibly involve a wider external influence, such as the WAHO and United Nations agencies. ${ }^{20}$ The participants also proposed a central pool for research funding (counter-part funding - where donors require that recipient countries contribute some of its own funds to projects) for both health research (HPSR inclusive) and research generally. 
It was encouraging to note that all except one country had a research plan/program in place in contrast to findings from earlier studies among African countries. ${ }^{10,21}$ However, the participants decried the inadequacy of capacities for HPSR - particularly in directorates of research - as well as the disconnect between decision makers in ministries of health and researchers in universities.

Weak capacity for health research among countries in West Africa has been demonstrated in previous studies. ${ }^{10}$ This study represents a loud call for more work on both institutional- and individual-level capacity building and support towards conducting HPSR. It is, however, worthy of note that interventions to improve both policy maker and researcher capacity and linkage for HPSR and evidence use in policy making have been shown to be effective. These include secondment and exchange models, mentorship, research methods and scientific writing workshops, research and re-entry support grants, postdoctoral research support and placements, as well as grants for networking and scholarly conferences attendance. ${ }^{22-28}$ These strategies need to be further deployed and institutionalised in settings where they are lacking or suboptimal.

\section{Strengths and limitations}

This is the one of the few studies to explore the status of funding for HPSR in Africa. The study also provided perspectives from both Anglophone and Francophone countries. There have been a number of previous studies that reported the status of health research systems in Africa which identified constraints similar to those identified in this study regarding HPSR funding. These include inadequate research infrastructure, limited resource mobilisation skills and donor dependence. However, this study did not include all the West African countries and this could limit the generalisability of the findings. A key limitation of this study is that it was based on self-reports, however this limitation was adjusted for by conducting a desk review as part of the study. Another limitation was the challenge of effectively using a phenomenological approach in conducting qualitative interviews done via phone calls and a videoconferencing application. Although we supported the in-depth interviews with the desk review of relevant literature, there was a dearth of published literature on the subject. We were able, to a reasonable extent, to understand the problems our study participants face with regards to HPSR funding.

The lack of systematically available data on HPSR funding is because there has been very little research commissioned and undertaken on the subject in the West African subregion. Furthermore, there are inherent methodological challenges in conducting research on HPSR funding. The lack of sufficient interest in HPSR by policy actors and the political class is also a major factor in the lack of funding for it. With increasing awareness of the value of HPSR across the West African region, it is hoped that a regional organisations such as the WAHO will participate actively to drive the promotion of HPSR among member countries.

\section{Conclusion}

This study showed that both health research and HPSR were considered a low priority, with no designated funding (budget line) and funding dissemination in the surveyed countries in West Africa. Some of the determinants of government expenditure which might impact on funding for health research and HPSR include: availability of revenue; population size; inflation; misallocation; conflicting priorities; political ideologies; policy actors' interests; political will and government bureaucracies/processes. All these factors are widely recognised to play a vital role in determining the level of funding channelled into any program by the government.

These factors should be given due consideration as part of the steps that are needed within advocacy efforts geared towards increasing the level of funding to both health research and HPSR. Health research in these countries was largely prioritised and funded by the donor agencies, often without recourse to the countrylevel health priorities. There was also limited capacity for conducting research generally and HPSR specifically. Given donor fatigue, transition of donor funding and the pivotal role of HPSR in health systems strengthening, there is an urgent need for West African states to commit to prioritising and funding HPSR and HPSR capacity development.

\section{Acknowledgements}

This work was supported by the Alliance for Health Policy and Systems Research, World Health Organization The authors are themselves alone responsible for the views expressed in the article. This article does not represent the views, decisions, or policies of the Alliance for Health Policy and Systems Research.

\section{Peer review and provenance}

Externally peer reviewed, invited.

\section{Competing interests}

None declared.

\section{Author contributions}

All authors made a significant contribution to the work reported, including the conception, study design, execution, acquisition of data, analysis and interpretation, or in all these areas; took part in drafting, revising or 
critically reviewing the article; gave final approval of the version to be published; have agreed on the journal to which the article has been submitted; and agree to be accountable for all aspects of the work.

\section{References}

1. World Health Organization. Changing mindsets: strategy on health policy and systems research. Geneva; WHO; 2012 [cited 2021 Oct 26]. Available from: apps.who.int/ iris/bitstream/handle/10665/77942/9789241504409_eng. pdf

2. Adam T, Ahmad S, Bigdeli M, Ghaffar A, Røttingen JA. Trends in health policy and systems research over the past decade: Still too little capacity in low-income countries. PLoS One. 2011;6(11):e27263.

3. Shroff ZC, Javadi D, Gilson L, Kang R, Ghaffar A. Institutional capacity to generate and use evidence in LMICs : current state and opportunities for HPSR. Heal Res Policy Syst. 2017;15:94.

4. Grépin KA, Pinkstaff CB, Shroff ZC, Ghaffar A. Donor funding health policy and systems research in low- and middle-income countries: how much, from where and to whom. Heal Res Policy Syst. 2017;15:68.

5. Vega J, Shroff ZC, Sheikh K, Agyepong IA, Tilahun B, Tangcharoensathien $\mathrm{V}$, et al. Capacity, committed funding and co-production - institutionalizing implementation research in low- and middle-income countries. Health Policy Plan. 2020;35:ii7-ii8.

6. Khamis AM, Bou-karroum L, Hakoum MB, Al-gibbawi M, Habib JR, El-jardali F, et al. The reporting of funding in health policy and systems research: a cross-sectional study. Heal Res Policy Syst. 2018;16:83.

7. Oleribe OO, Nwanwanyu O. Foreign aid or foreign investments - call for a paradigm shift in mentality and nomenclature. Pan Afr Med J. 2015;20:214

8. Viergever RF, Hendriks TCC. The 10 largest public and philanthropic funders of health research in the world: what they fund and how they distribute their funds. Heal Res Policy Syst. 2016;14:12.

9. Sombié 1, Johnson E, Aidam J. [Funding for national ethics committees for health research in Member States of the Economic Community of West African States]. Rev Epidemiol Sante Publique. 2019;67(1):7-11.

10. Sombié I, Aidam J, Konaté B, Somé TD, Kambou SS. The state of the research for health environment in the ministries of health of the Economic Community of the West African States (ECOWAS). Heal Res Policy Syst. 2013;11:35.

11. Uneke CJ, Sombie I, Keita N, Lokossou V, Johnson E. An assessment of national maternal and child health policymakers' knowledge and capacity for evidence-informed policy-making in Nigeria. Int J Health Policy Manag. 2017;6(6):309-16.
12. Giorgi A. Sketch of a psychological phenomenological method. In: Giorgi A, ed. Phenomenology and psychological research: essays. Pittsburgh, $\mathrm{Pa}$ : Duquesne University Press; 1985.

13. Albert M, Fretheim A, Maïga D. Factors influencing the utilization of research findings by health policy-makers in a developing country: the selection of Mali's essential medicines. Heal Res Policy Syst. 2007;8:1-8.

14. Gómez, EJ. Civil society in global health policymaking: a critical review. Global Health. 2018;14:73.

15. World Scholarship Forum. 15 best universities in West Africa 2021. Owerri Imo State Nigeria: World Scholarship Forum; 2021 [cited 2021 Nov 4]. Available from: worldscholarshipforum.com/universities-west-africa/

16. Meghani A, Abdulwahab A, Privor-Dumm L, Wonodi C. Basket funds: a pooled arrangement to finance primary health care delivery and address the funding flow in Nigeria. Baltimore, MD: International Vaccine Access Center, Johns Hopkins Bloomberg School of Public Health; 2015 [cited 2021 Nov 4]. Available from: www. jhsph.edu/ivac/wp-content/uploads/2018/04/Basket_ Funds_pooled_arrangement_to_finance_primary_health_ care.pdf

17. The Sprout Fund. Sprout field guide for philanthropy \& civic action: what is catalytic funding? Pittsburgh: The Sprout Fund [cited 2021 Nov 4]. Available from: fieldguide.sproutfund.org/catalytic-funding/what-iscatalytic-funding/

18. Devi Sridhar. Seven challenges in international development assistance for health and ways forward. J Law, Med Ethics. 2010;38(3):459-69.

19. Mbondji PE, Kebede D, Zielinski C, Kouvividila W, Sanou I. Overview of national health research systems in sub-Saharan Africa : results of a questionnaire-based survey. J R Soc Med. 2014;107(IS):46-54.

20. Sombié I, Aidam J, Montorzi G. Evaluation of regional project to strengthen national health research systems in four countries in West Africa: lessons learned. Heal Res Policy Syst. 2017;15(Suppl 1):46.

21. Kirigia JM, Wambebe C. Status of national health research systems in ten countries of the WHO African Region. BMC Health Serv Res. 2006;6:135.

22. Uneke CJ, Sombie I, Uro-chukwu HC, Mohammed YG, Johnson E. Promoting evidence informed policymaking for maternal and child health in Nigeria: lessons from a knowledge translation workshop. Heal Promot Perspect. 2018;8(1):63-70.

23. Uneke CJ, Ezeoha AE, Uro-chukwu H, Thecla C. Promoting evidence to policy link on the control of infectious diseases of poverty in Nigeria: outcome of a multi-stakeholders policy dialogue. Health Promot Perspect. 2015;5(2):104-15. 
24. Uneke CJ, Sombie I, Keita N, Lokossou V, Johnson E, Ongolo-Zogo P. An assessment of policymakers' engagement initiatives to promote evidence informed health policy making in Nigeria. Pan Afr Med J. 2017;27:57.

25. Uneke CJ, Langlois E V, Uro-chukwu HC, Chukwu J, Ghaffar A. Fostering access to and use of contextualised knowledge to support health policy-making: lessons from the Policy Information Platform in Nigeria. 2019;4:1-12.

26. Uneke CJ, Ezeoha AE, Uro-chukwu HC, Ezeonu TC, Igboji J. Promoting researchers and policy-makers collaboration in evidence-informed policy-making in Nigeria: outcome of a two-way secondment model between university and health ministry. Int $\mathrm{J}$ Health Policy Manag. 2018;7(6):522-31.
27. Onwujekwe O, Etiaba E, Mbachu C, Arize I, Nwankwor C, Ezenwaka $U$, et al. Does improving the skills of researchers and decision-makers in health policy and systems research lead to enhanced evidence-based decision making in Nigeria? - A short term evaluation. PLoS One. 2020;15(9):e0238365.

28. Izugbara CO, Kabiru CW, Amendah D, Dimbuene ZT, Pythagore $\mathrm{H}$, Donfouet $\mathrm{P}$, et al. "It takes more than a fellowship program": reflections on capacity strengthening for health systems research in sub-Saharan Africa. BMC Health Serv Res. 2017;17(Suppl 2):696.

\section{Copyright: (c) (i)}

(C) 2021 Uneke et al. This article is licensed under the Creative Commons Attribution-ShareAlike 3.0 International Licence, which allows others to redistribute, adapt and share this work for any purpose provided they attribute the work and indicate if changes were made. See: https://creativecommons.org/licenses/by/3.0/igo/ 